\title{
Effects of salting and drying on the deterioration rate of fermented parkia biglobosa seed
}

\begin{abstract}
The present study described the use of percentage moisture left and salting as a preservative method in studying the shelf life of fermented Parkia biglobosa (African Locust bean seed) over a period of four weeks. Bacillus subtilis was used as starter culture in the fermentation of Parkia biglobosa to 'Iru'. Fermented samples [Iru] were dried to various\% moisture content and salt of various concentrations were added. Samples were stored for four weeks at room temperature in an air tight plastic container. Functional properties such as $\mathrm{pH}, \%$ protein, $\%$ titratable acidity and peroxide value of the seeds were analyzed on weekly basis during the storage period. Protein concentration of the preserved samples varied with different drying time and $\%$ salt added. There was an increase in titratable acidity and peroxide values towards acidity during preservation.
\end{abstract}

Keywords: fermentation, parkia biglobosa, bacillus subtilis, moisture, deterioration, shelf life

\author{
Volume 8 Issue I - 2018
}

\author{
Modupe Elizabeth Ojewumi,' James Abiodun \\ Omoleye,' Ayodeji Ayodele Ayoola,' Adesola \\ Adetutu Ajayi, ${ }^{2}$ Bosede Temitope Adekeye, ${ }^{2}$ \\ Alaba Oladipupo Adeyemi ${ }^{3}$ \\ 'Chemical Engineering Department, Covenant University, \\ Nigeria \\ ${ }^{2}$ Microbiology Department, Covenant University, Nigeria \\ ${ }^{3}$ Biochemistry Department, Covenant University, Nigeria \\ Correspondence: Modupe Elizabeth Ojewumi, Faculty of \\ Engineering, Chemical Engineering Department, Covenant \\ University, P.M.B. 1023, Sango Ota, Ogun State, Nigeria, Tel +234 \\ 8028159149, \\ Email modupe.ojewumi@covenantuniversity.edu.ng
}

Received: November 14, 2017 | Published: January 22, 2018

\section{Introduction}

Fermentation is the biological conversion of complex substrates such as starch or sugar into simple compounds by various microorganisms such as fungi and bacteria. ${ }^{1}$ It is one of the oldest forms of food preservation known to man. ${ }^{2}$ Microorganisms require certain basic nutrients for growth and maintenance of metabolic functions. The amount and type of nutrients required depends on the microorganism. These nutrients include water, a source of energy, nitrogen, vitamins, and minerals. ${ }^{3,4}$ Shelf life is defined as the period from when the product is produced/manufactured until the time it is intended to be consumed. Several factors are used to determine a product's shelf life, ranging from organoleptic qualities to microbiological safety.

Leguminous seeds account for up to $80 \%$ of dietary protein which may be the only source of protein for some groups. Their cooked forms are eaten as meals and are commonly used in fermented form as condiments to enhance the flavours of foods. ${ }^{5-9}$ Parkia biglobosa tree has been used both locally and internationally in drug manufacturing and cosmetics production..$^{10}$ Despite the important uses, the populations of this tree is reducing and it remain semi or undomesticated. $^{10,11}$ Fermented African locust beans is known by different names in different countries-kinda in Sierra Leone, Iru or dawadawa in Nigeria and Ghana, ${ }^{12-14}$ Afintin and sonru in Benin republic, ${ }^{13}$ and natto in Japan. ${ }^{13,14}$ Till date, the production process is a traditional art; and the fermentation is carried out by indigenous microflora derived from the immediate environment. ${ }^{15}$

Other seeds such as melon seed, castor oil seed, mesquite bean and soybean are also fermented to give condiments. ${ }^{16}$ At some stages in the preparation of the seed, fermentation is required to bring out the desired nutritional value and other organoleptic properties such as taste, flavor and texture. Previous studies have shown that fermentation improves the digestibility, nutritive value and flavor of the raw seeds. ${ }^{5,16}$ The bacteria responsible for the fermentation of Parkia biglobosa has being identified to be Bacillus subtilis and Staphylococcus. ${ }^{10,15-22}$

Food preservation is the process of treating and handling food to stop or greatly slow down spoilage (loss of quality, edibility or nutritive value) caused or accelerated by micro-organisms. ${ }^{12}$ Preservation usually involves preventing the growth of bacteria, fungi and other micro-organisms, as well as retarding the oxidation of fats which cause rancidity. It also includes processes to inhibit natural ageing and discoloration that can occur during food preparation such as the enzymatic browning reaction.

According $t^{23}$ amongst the various factors working against traditional fermented foods is lack of durability (shelf life). Hence, fermentation has to be controlled/stopped after sometime to prevent further microbial growth which can lead to spoilage. This can be achieved by preserving the seed after processing. In order to improve the shelf life, a major challenge to its stability, we have carried out the effect of moisture content and drying on its deterioration. 'Iru' has a shelf life of 2 to 3 days without additives, which implies that the producer or processor has to dispose off the product within three days if not consumed. The bacteria, yeast and molds responsible for deterioration needs moisture for their metabolism which has to be eliminated totally in order to keep them off. In order to overcome the problems encountered by the processors of 'Iru' in keeping this product for a long time, the deterioration rate was studied.

\section{Materials and methods}

Raw locust bean seed was procured from a local market at Ota Ogun state. It was processed according to ${ }^{1}$ method. 


\section{Preparation of stater culture}

The bacillus subtilis used was prepared according to the method used by. ${ }^{2}$

\section{Preparation of seed for fermentation process}

$600 \mathrm{~g}$ of processed African locust bean seed were fermented in the laboratory for three days (72hours) using Bacillus subtilis. The fermented seed were portioned into three parts: the first part was oven dried while the second part was portioned into three batches and various salt concentrations of 1,2 and 3\% salt were added, the third portion was used as control.

\section{Deterioration study}

The deterioration monitoring was carried out within a period of four weeks (28days). The \% moisture content was calculated until constant weight was obtained at $12-16$ hours which is close to $0 \%$ moisture content. Samples were allowed to cool in a desiccator and stored in an air tight container for 28days at room temperature. Analysis was carried out weekly.

\section{$\mathrm{pH}$ determination}

Method $^{1}$ was used for the determination of $\mathrm{pH}$.

\section{Determination of titratable acidity (TA) and\% protein}

These were both done using ${ }^{12}$ method.

\section{Determination of peroxide value (POV)}

Method $^{12}$ was used for the determination of Peroxide value

\section{Results and discussion}

\section{pH}

Figure $1 \&$ Figure 2 shows the effect of storage time on the $\mathrm{pH}$ of the two different methods of preservation used in this work. The more the storage days the more the $\mathrm{pH}$ towards acidic medium, hence the lower the risk and rate of spoilage, since some microorganisms finds it difficult to strive in an acidic medium. Increase in $\mathrm{pH}$ towards the acidic range were recorded for drying durations 8-16hours and $2-3 \%$ salted samples. Increasing the acidity of foods, either through fermentation or the addition of weak acids, has been used as a preservation method since ancient times. Increase in $\mathrm{pH}$ towards alkalinity were noticed at 2-6hours, this was responsible for the spoilage notice within these period, as microorganism grows best in an alkaline medium. The increase in $\mathrm{pH}$ observed in this study towards alkalinity is an indication that fermentation still continued after the processing period of 'Iru' (post fermentation operation). This confirmed that the organisms responsible for the fermentation are still present at consumption. Earlier studies have confirmed that the fermentation parkia biglobosa seed to Iru is an alkaline fermentation which is a fermentation process during which the $\mathrm{pH}$ of the substrate increases to alkaline values that may be as high as $\mathrm{pH} 9 .^{24,25}$ The effect of drying on the $\mathrm{pH}$ of the fermenting system were monitored as well as various salt $\%$ composition. The result obtained confirmed that the fermentation of Parkia biglobosa seeds to 'Iru' is an alkaline fermentation since $\mathrm{pH}$ increased towards alkalinity during storage for both the control (Figure 3) and the wet (0hour) samples, indicating post fermentation process. This gives the reason why water should be completely removed from fermented African locust bean in order to increase its shelf life. Deterioration was noticed on the third day for both samples, but never in the 8-16hours dried samples and 2-3\% salted samples, however, a dark brown colouration was observed due to oxidative deterioration as a result of high concentrations of unsaturated fat which always manifests in form of discoloration.

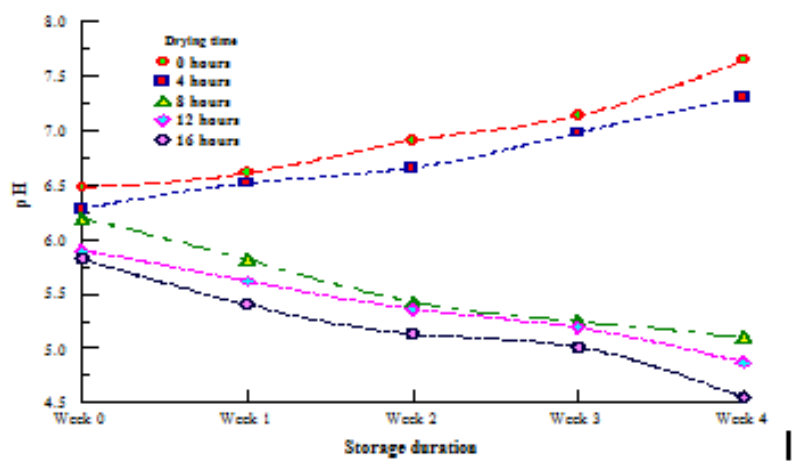

Figure I Effect of moisture level and storage days on the $\mathrm{pH}$ of dried samples.

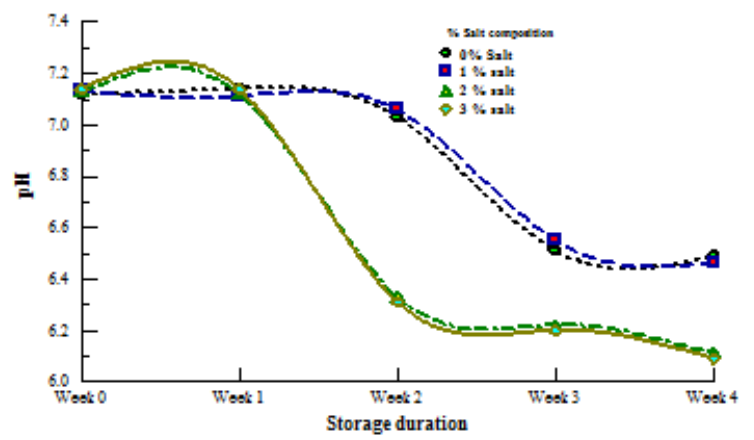

Figure 2 Effect of Storage days on the $\mathrm{pH}$ of samples preserved with various $\%$ of salt.

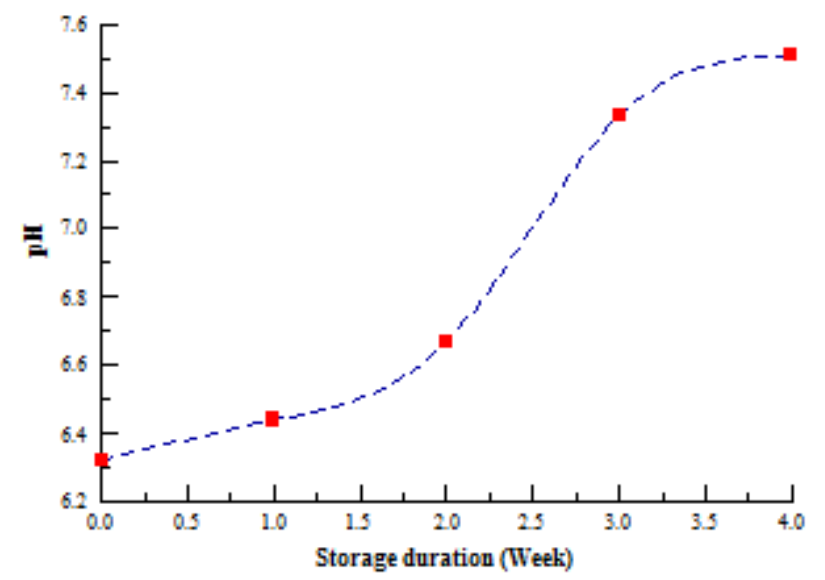

Figure 3 Effect of Storage days on the $\mathrm{pH}$ of control samples.

\section{Protein composition}

Literature revealed that fermentation of African locust bean seeds increases the protein content which is the major reason while the fermented seed is being consumed by man. Other reason is the aroma it gives to food as a condiment in soup. However, this work 
confirmed that excessive heating denatures the structures of protein which led to its reduction during storage. Figure 4 shows the result obtained from protein analysis carried out on the bacillus subtilis fermented dried samples at various drying time. Samples stored (wet) without drying had a tremendous decrease in the protein content during storage due to fast deterioration rate as a result of an increase in the $\mathrm{pH}$ towards alkalinity. For samples dried for 4-8hours a higher protein concentration which decreased with storage time was noticed and same trend was observed in all the remaining samples during deterioration study. The long hours of drying probably denatured the protein structure which led to the decrease with storage duration.

Figure 5 shows that the protein concentration of the non-salted samples decreases with storage (control), also an Offensive and pungent odour was noticed as storage progresses. The protein content at week 0 and $0 \%$ salt decreased with respect to storage and spoilage was noticed on the third day with maggot infestation and mold growth. It was observed that after the first week of storage, the sample with $2-3 \%$ salt concentration had close protein concentration throughout the storage study, this inferred that the quantity of salt used had no effect on the protein content, however a dark brown colouration was noticed after two weeks of storage. Deterioration was not noticed until the third week of preservation for $1 \%$ salted sample. Some of the moisture had been removed by the salt, since salt draws water out of cells via the process of osmosis, therefore the samples had a drier look with an acceptable odour at week 4 for 2 and 3\% salted samples.

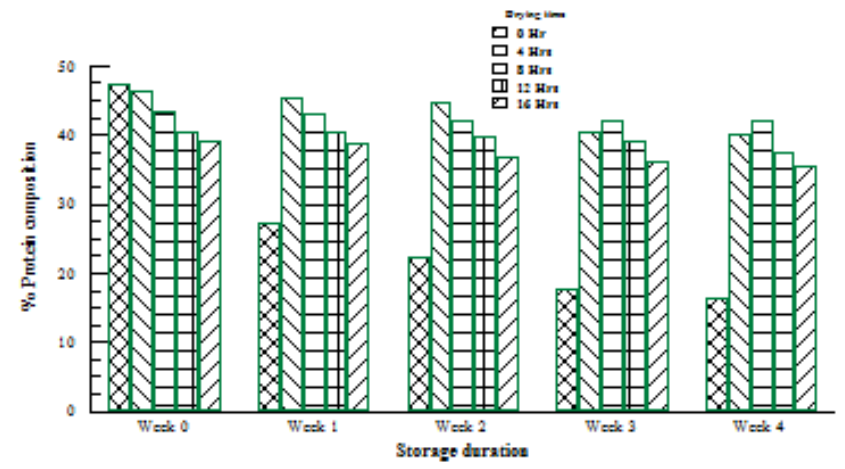

Figure 4 Effect of storage on the protein composition for Bacillus subtilis fermented dried samples.

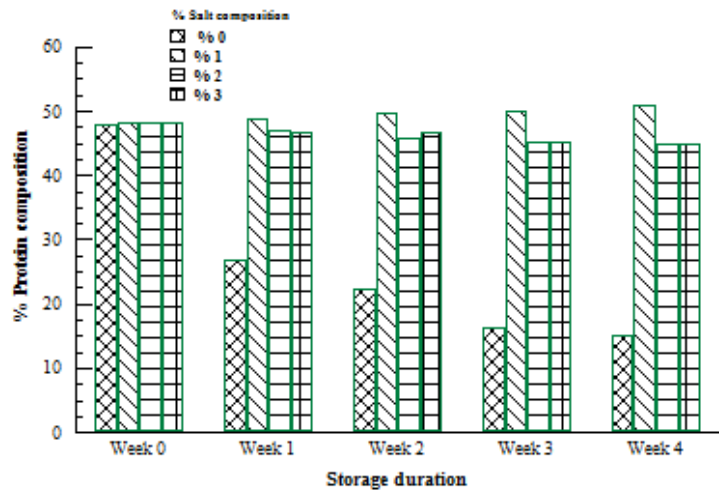

Figure 5 Effect of storage on protein analysis for samples preserved with salt.

\section{Titratable acidity analysis}

Figure $6 \&$ Figure 7 shows the effect of storage time on the titratable acidity for all the samples. A significant increase in titratable acidity with storage time was noticed, which is as a result of some acid producing processes going on during the deterioration stage. The significance of the increase in both $\mathrm{pH}$ and titratable acidity in stored 'Iru' is the continuation of fermentation process in storage. The simultaneous increase of the two in 'Iru' have been reported by ${ }^{26,27}$ The increase is attributed to the activities of proteolytic enzymes which takes place in the degradation of protein and the hydrolysis of carbohydrates components to sugar and organic acids.

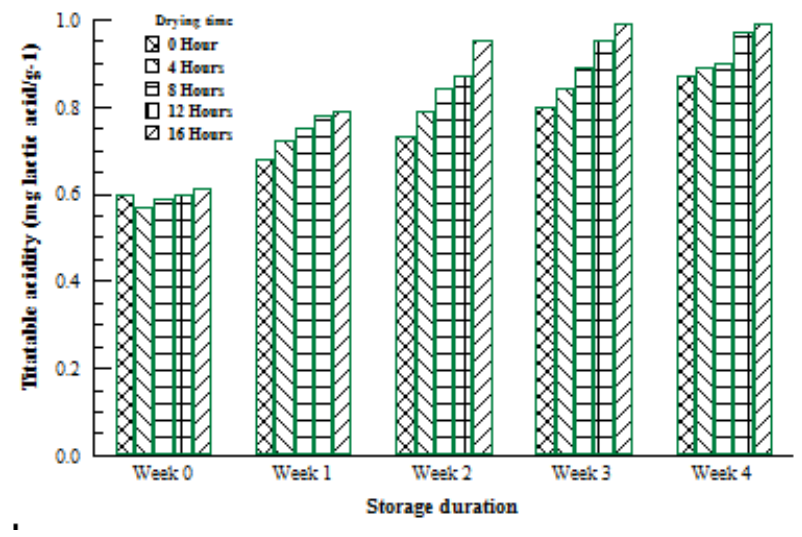

Figure 6 Effect of storage on titratable acidity for Bacillus subtilis fermented dried samples.

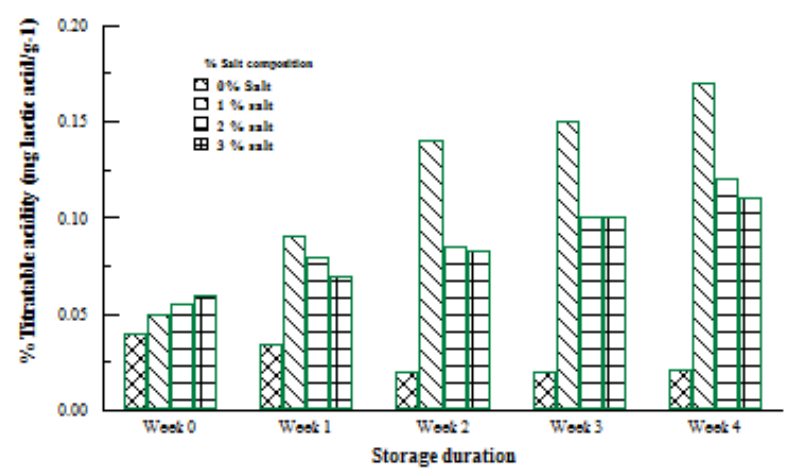

Figure 7 Effect of storage on titratable acidity analysis for samples preserved with salt.

\section{Peroxide value}

Figure 8 \& Figure 9 shows the effect of storage time on the Peroxide value in stored fermented samples of Parkia biglobosa seeds. Peroxide values give the initial evidence of rancidity in an unsaturated fats and oil. Findings showed that peroxidation of stored 'Iru' increased with storage duration. ${ }^{28} \mathrm{An}$ increase in peroxide value is an indication of fat deterioration which brings rancidity. This work reported an increase in the peroxide value of stored 'Iru' both dried and salted samples, which is a good predictor that peroxidation occurred during the storage of 'Iru'. The higher the peroxide value, the more susceptible is the condiments to spoilage, which is caused by fat. Although fat acts as flavour retainer and increase mouth feel of food, ${ }^{29}$ it can also act otherwise if goes rancid. Fatty foods with peroxide value ranging from $20-40 \mathrm{meg} / \mathrm{kg}$ is rancid, peroxide value should be less than 10milliequivalents $/ \mathrm{kg}{ }^{21,25}$ Oxidation is one of the major causes of deterioration in any protein based foods since they are very rich in fat. 'Iru' becomes susceptible to oxidative deterioration due to its high concentrations of unsaturated fat which always manifests in 
form of discoloration, formation of toxic compounds, poor shelf life, development of off flavour, nutrient losses, respectively with storage duration.

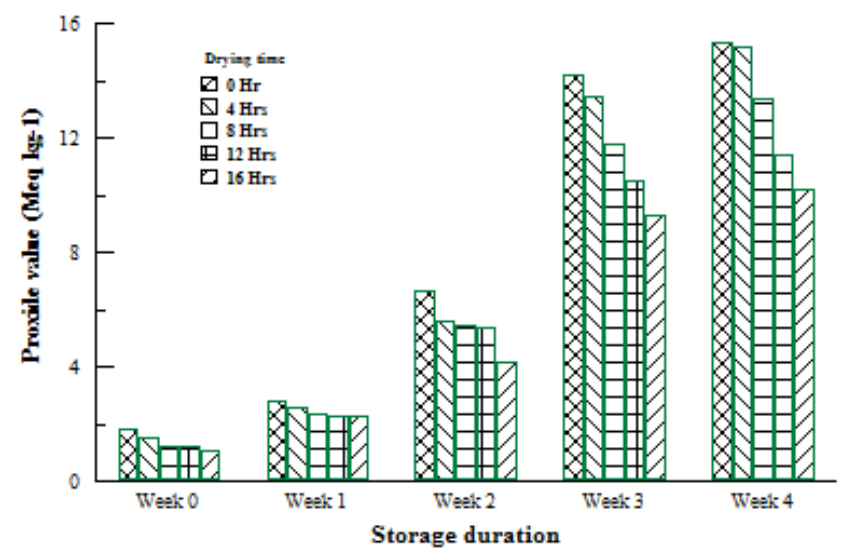

Figure 8 Effect of storage on peroxide value for Bacillus subtilis fermented sample.

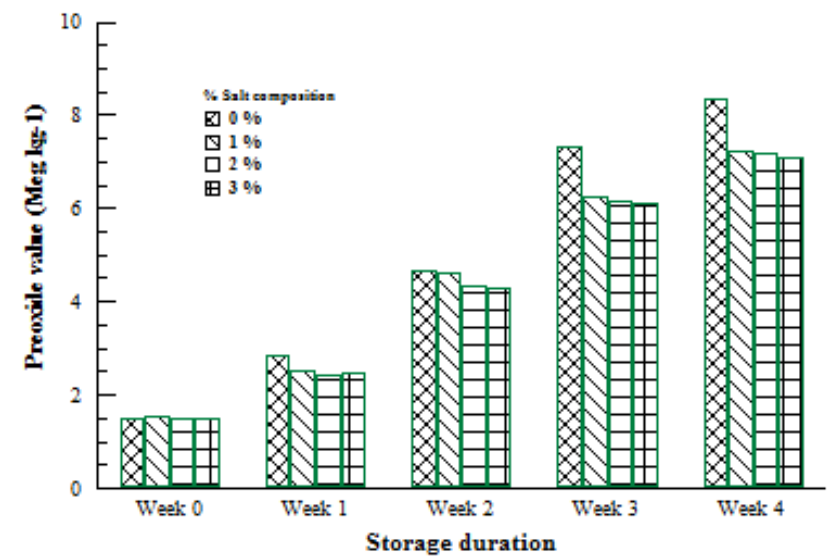

Figure 9 Effect of storage on peroxide value for sample salt.

For the control sample e.g. Figure 3, deterioration was noticed on the second day since the medium of the samples were alkaline, fungi (mold or yeast) growth was encouraged which led to spoilage after the third day of storage. Smell like that of ammonia was noticed on the second day of storage which increased as storage progressed. One of the by-products of yeast is ammonia, an alkaline gas that forms when the yeast ferments sugar. Maggot with strong ammonia in form of a choking pungent smell was noticed at the beginning of the fourth day in the first week of storage for wet stored samples. Brown colouration was noticed which can be attributed to the phenolic compounds present in the fermented samples. Increase in the strength of flavour was noticed in this work which may be attributed to the presence of volatile organic compounds

\section{Conclusion}

This work concluded that to increase the shelf life of fermented African locust bean seeds, water must be totally eliminated from it. Total dryness of the fermented condiment will preserve the seed and increase its utilization especially in protein deficient food formulation. This will reduce scarcity (due to very short shelf life) and improve its availability all year round. Drying will also get rid of the undesirable smell which has made Iru unpopular in the urban region. Lowering the $\mathrm{pH}$ of a food increases the effectiveness of an organic acid as a preservative.

\section{Acknowledgements}

The authors appreciate the partial sponsorship of Covenant University.

\section{Conflict of interest}

The authors declare that they have no conflict of interest.

\section{References}

1. Modupe EO, Abiodun JO, Adesola AA. The Effect of Starter Culture on the Protein Content in Fermented African Locust Bean (Parkia biglobosa) Seed. International Journal of Engineering Research \& Technology. 2016;5(4):249-255.

2. Ojewumi ME, Omoleye JA, Ajayi AA. Optimum Fermentation Temperature for the Protein Yield of Parkia biglobosa Seeds (Iyere). Proceeding of the $3^{\text {rd }}$ International Conference on African Development Issues (CUICAD), 2016:584-587.

3. Mossel DAA, Corry JEL, Struijk CB, et al. Essentials of the Microbiology of foods: a textbook for advanced studies. England: John Wiley and Sons; 1995:699.

4. Jay JM. Modern food microbiology. 6th ed. Maryland: Aspen Publishers, Inc; 2002:679.

5. Odunfa SA. Carbohydrate changes in fermenting locust bean (Parkia filicoidea) during iru Preparation. Plant Foods and Human Nutrition. 1985;32(1):1-10.

6. Aidoo KE. Lesser-known fermented plant foods. Tropical Science. 1972;26:249-252.

7. Achi OK. Traditional fermented Protein condiments in Nigeria. African Journal of Biotechnology. 2005;4(13):1612-1621.

8. Achi OK. Microbiology of "Obiolor" a Nigerian fermented non-alcoholic Beverage. Journal of Applied Microbiology. 2008;69(3):321-325.

9. Oniofiok N, Nnayelugo DO, Ukwondi BE. Usage patterns and contributions of fermented foods to nutrient intake of low-income households in Emene Nigeria. Plant Foods Hum Nutr. 1996;49(3):199-211.

10. Ojewumi ME. Optimizing the Conditions and processes for the production of Protein Nutrient from Parkia biglobosa seeds. Nigeria: Department of Chemical Engineering, Covenant University; 2016.

11. Teklehaimanot Z. Exploiting the potential of indigenous agroforestry trees:Parkia biglobosa and Vitellaria paradoxa in sub-Saharan Africa. Agroforestry System. 2004;61(1-3):207-220.

12. Modupe Elizabeth Ojewumi, Abiodun J Omoleye, Adesola Ajayi. The Study of the Effect of Moisture Content on the Biochemical Deterioration of Stored Fermented Parkia biglobosa Seeds. Open Journal Engineering Research and Techonolgy. 2016;1(1):14-22.

13. Azokpota P, Hounhouigan DJ, Nago MC. Microbiological and chemical Changes during the fermentation of African locust bean (Parkia biglobosa) to produce afintin, iru and sonru, three traditional condiments produced in Benin. Int J Food Microbiol. 2005;107(3):304-309.

14. Beaumont M. Flavouring Composition prepared by fermentation with Bacillus subtilis spp. Int J Food Microbiol. 2002;75(3):189-196.

15. Olabiwonninu AA, Olaoluwa I, Odunfa SA. Riboflavin enriched iru: A Fermented vegetable protein. African Journal Microbiology Research. 2017;11(13):546-552. 
16. Omafuvbe BO, Falade OS, Osuntogun BA, et al. Chemical and biochemical changes in African locust bean (Parkia biglobosa) and melon (Citrullus vulgaris) seeds during fermentation to condiments. Pakistan Journal of Nutrition. 2004;3(3):140-145.

17. Antai SP, Ibrahim MH. Microorganisms Associated with African locust Bean (Parkia filicoidea Welw) fermentation for dawadawa production. Journal Applied Bacteriology. 1986;61(2):145-148.

18. Odunfa SA, Oyewole OB. African fermented foods. In: Wood BJB, editor. Microbiology of fermented Foods. UK: Blackie Academic and Professional; 1998. p. 713-746.

19. Odunfa SA. Biochemical changes in fermentation of African Locust Bean (Parkia Biglobosa) during the 'Iru' Fermentation. Journal Food Technology. 1985;20(3):295-303.

20. Abiose SH, Atalabi TA, Ajayi LO. Fermentation of African Locust beans: Microbiological and biochemical studies. Nigerian Journal of Biological Sciences. 1986;1:109-114.

21. Suberu HA, Akinyanju JA. Starter culture for the production of soyiru World Journal of Microbiology \& Biotechnology. 1996;12(4):403-404.

22. Ouoba LII, Cantor MD, Diawara B, et al. Degradation of African locust bean oil by Bacillus subtilis and Bacillus pumillus isolated from soumbala, a fermented African locust bean condiment. J Appl Microbiol. 2003;95(4):868-873.
23. Sarkar PK, Tamang JP. Changes in the microbial profile and proximate composition during and controlled fermentations of soya beans. Food Microbiology. 1995;12:317-325.

24. Ikenebomeh MJ.African locust bean fermentation-some physico-chemical Parameters. Nigerian Journal of Applied Science. 1986;4:101-108.

25. Wagenknecht AC, Mattick LR, Lewin LMH, et al. Changes in soybean lipids during tempeh fermentation. Journal of Food Science. 1986;26(4):373-376.

26. Kolapo AL, Popoola TOS, Sanni MO. Evaluation of Biochemical Deterioration of Locust Bean Daddawa and Soybean Daddawa-Two Nigerian Condiments. American Journal Food Technology. 2007;2:440-445.

27. Kinsella JE, Melachouris N. Functional Properties of proteins and foods. Journal of Food Science and Nutrition. 1976;34(3):182-189.

28. Nout MJR. Fermented food and food Safety. Journal Food Research International. 1994;27(3):291-298.

29. Omafuvbe BO, Shonukan O, Abiose S. Microbiological and biochemical changes in the traditional fermentation of soybean for soy- daddawa -a Nigerian food condiment. Journal of Food Microbiology. 2004;17(5):469-474. 